\title{
Students involvement into social and cultural activity: modeling and motivation
}

\section{Participación de los estudiantes en la actividad social y cultural: modelado y motivación}

GUTMAN, Eugeniya*†, TERENTYEVA, Irina, GAIDAMASHKO, Igor and FAKHRUTDINOVA, Anastsiya

Kazan Federal University, Russia.

ID $1^{\text {st }}$ Author: Eugeniya, Gutman

ID $1^{\text {st }}$ Co-author: Irina, Terentyeva

ID $2^{\text {nd }}$ Co-author: Igor, Gaidamashko

ID $3^{\text {rd }}$ Co-author: Anastsiya, Fakhrutdinova

DOI: $10.35429 /$ EJM.2021.27.12.23.29

Received: July 25, 2021; Accepted: December 30, 2021

\begin{abstract}
At present, higher education is undergoing major changes related to the implementation of the Bologna process ideas, education informatization, integrative processes in society, increasing competition, and globalization. In this regard, the problem of student involvement formation acquires exceptional importance in the university educational activity. The focus on student involvement formation in higher education's social and cultural activity process is conditioned by the necessity to improve professional personality development and raise social competencies. We consider the social activity as a person's integral quality which is realized in various types of self-activity, in the process of which the personality self-realization occurs, conditioned by objective and subjective factors. Also, the structure of motives for young people's social activity is considered. Students' involvement is seen as a person's property, which externalizes in activity and shows the person's attitude to its various spheres. Particular importance is paid to the research of the students' extracurricular organization. It is shown that the students free time is needed to organize in the process of educational activity to create conditions for self-realization and self-actualization of the student's personality. The submissions of the article can be useful for Faculty and Administration of higher education institutions.
\end{abstract}

Higher education, Motivation, Social communication, Structure of motives, University

\begin{abstract}
Resumen
En la actualidad la educación superior está experimentando importantes cambios relacionados con la implementación de las ideas del proceso de Bolonia, la informatización de la educación, los procesos integradores en la sociedad, la creciente competencia y la globalización. En este sentido, el problema de la formación de la participación de los estudiantes adquiere una importancia excepcional en la actividad educativa universitaria. El foco en la problemática de la formación del involucramiento del estudiante en el proceso de actividad social y cultural en la educación superior está condicionado por la necesidad de mejorar el desarrollo profesional de la personalidad y el aumento de las competencias sociales. Consideramos la actividad social como una cualidad integral de la persona que se realiza en diversos tipos de autoactividad, en cuyo proceso se produce la autorrealización de la personalidad, condicionada por factores objetivos y subjetivos. Asimismo, se considera la estructura de motivos de la actividad social de los jóvenes. La participación de los estudiantes se ve como una propiedad de una persona, que se exterioriza en la actividad y muestra la actitud de la persona hacia sus diversas esferas. Se le da especial importancia a la investigación de la organización extraescolar de los estudiantes, donde se demuestra que el tiempo libre de los estudiantes es necesario para organizar en el proceso de la actividad educativa con el propósito de crear condiciones para la autorrealización y la autorrealización de la personalidad. Las presentaciones del artículo pueden ser útiles para el profesorado y la administración de instituciones de educación superior.
\end{abstract}

Educación superior, Motivación, Comunicación social, Estructura de motivos, Universidad

Citation: GUTMAN, Eugeniya, TERENTYEVA, Irina, GAIDAMASHKO, Igor and FAKHRUTDINOVA, Anastsiya. Students involvement into social and cultural activity: modeling and motivation. ECORFAN Journal-Mexico. 2021. 12-27:23-29.

\footnotetext{
* Correspondence to Author (Email: egutman@ rambler.ru)

$\dagger$ Researcher contributing first author.
} 


\section{Introduction}

University graduates' competitive recovery is one of the most recent problems of modern education, on which the future of individual universities and the educational systems of various countries, their position in the world educational services market, largely depends (Yudkevich, 2014). In the conditions of civil society reform, education, especially higher education, is seen as the main, leading factor of social and economic progress. The reason for this attention lies in the understanding that the most important value and the main capital of modern society is a person capable of finding, deepening knowledge, and adopting non-standard solutions (García Padilla, 2021).

Students should be prepared for a fastchanging labor market and environment, set clear goals and development priorities, and achieve their implementation. Quick, mobile response to ongoing changes in the conditions of individual and socio-economic development, the participation in the society and the state life, the realization of various social needs and interests lead to the willingness to learn new approaches in the content of professional activities, volunteerism and other forms of involvement (Fletcher et al., 2018; José Sá, 2020). The dynamic development of modern society puts the individual in a situation where he not only needs to adapt to society but also makes decisions that extract his personal abilities from the surrounding reality, so one of the main goals and important outcome of education should not be only the scope of knowledge is acquired, but also the development of motivation, voluntary characteristics, the formation of a value system (Levina et al., 2015; Hurtado et al., 2021).

In this regard, the problem of student involvement formation acquires exceptional importance in the university educational activity. Special importance in the formation of this inclusiveness is acquired by educational work aimed at cultural and recreational activities organizing in a modern university. Its specificity is "taking into account the characteristic features of university students thinking who have a specific attitude toward professional activity, so social and cultural activities are closely related to the student's educational activities" (Maslennikova et al., 2010).
It is not only the education quality indicator, but also creates the conditions for self-fulfillment, and also complements and widens the horizons of the university educational process, helps the student to spend his free time with benefit for his development and needs (Loginova, 2006; Quevedo Sánchez, 2021).

The focus on the formation of student participation in the process of social and cultural activities in higher education depends on the need to improve the efficiency of professional development and intensify its social functions. The process of social and cultural activities in the field of education modernization should have human characteristics, flexibility, non-violent and "noninterfering" educational process that can be tailored to the needs and interests of its members (Sibgatova et al., 2015; Sakhieva et al., 2015; Gutman, 2013; García Padilla, 2021).

The framework of the article does not allow us to consider all available approaches to the analysis of the concept of "social activity". We mean a social activity as a person's integral quality realized in various types of self-activity, in the process of which the personality self-realization occurs, conditioned by objective and subjective factors. Such a definition, in our opinion, allows: first, to point out the need to consider social activity in two ways: as a personal social quality and as a specific characteristic of one's activity - selfactivity, individual voluntary activity, as the unity of the personal and the public; and secondly, selfactualization and self-realization in some social spheres take place. In our article, we consider the student positive social activity - the person state and integrative property, expressed in one's readiness and ability to be a subject of social interaction in the process of obtaining higher education, to transform oneself and the environment for the benefit of society to achieve personal and socially oriented goals. We focus on this since foreign, and home sociologists especially note the fact when characterizing social and cultural activity process, we should not let go of the phenomenon of anticulture from the field of view - various types of subcultural movements, deviant behavior: criminal activity, offenses. Only when we consider the whole range of activities can we reproduce the complete picture of the social and cultural activity process (Loginova, 2006; Tough, 2007; Quevedo Sánchez, 2021). 


\section{Literature Review}

Today, the scientists' interest in the formation of students' social activity in the cultural activity process is associated with the high relevance of this problem in education globalization and internationalization. The state of instability, transitivity, the crisis of social development changes the forms and mechanisms of the social activity formation among young people, determines the study of its characteristics, factors, contradictions. The scientific literature has gathered theoretical foundations to determine the goals and solve the problems of students' involvement in the process of cultural and social activities (Yusof et al., 2020). The personality social activity is studied at different levels: its methodological aspect is being developed (for example Mashanov et al., 2014; Onufriieva et al., 2016); social aspect (for example, Popovych, 2016; Shamionov, 2018); psychological aspect (Romanova et al., 2018); pedagogical aspect (Maslennikova et al., 2010; Slastenin, 2004), the foreign experience of its development (Arnold \& Ducate, 2006; García Padilla, 2021).

Particular importance is attached to the study of the students' free time organization. It is shown that the student's free time is needed to organize in the process of an educational activity to create conditions for self-realization and selfactualization of the student's personality. Fakhrutdinova et al. (2019) consider the student's free time as a kind of a certain integrative activity, allowing the person to actively show one's worth, build relationships with the surrounding world.

Problems of formation, development, and stimulation of youth activity, identification of features of the motivating needs of a socially active person, including in the process of cultural activity, were considered by sociologists, pedagogues, and psychologists during all periods of the Russian state existence. However, in different periods the ideas about the active personality formed in society differed significantly. In comparative pedagogical studies of different years, attempts were made, on the one hand, to analyze the content of the concept of social activity, on the other hand, to identify the motives which direct and realize a human activity in significant social activity (Quevedo Sánchez, 2021).
According to researchers of youth movements in the 90-ies XX century, the motivation of social activity was the desire of the individual to meet the needs for self-realization, in social intercourse, in communication, the desire for individuality and independence. From their point of view, social activity is the sphere of personal strengths and abilities application, enriching the life content, filling it with a new meaning.

The analysis of educational and psychological research shows the significant attention of scientists to the problems of personal, social, and occupational development of specialists during the university years and by determining the subject's personal destiny, identifying the benefits of society and itself. The study stage at the university is considered the central period in the formation of future competitive specialist social and professional activity. The beginning of "economic activity" is connected with this period, by which demographers understand the inclusion of a person in independent, productive activity, the beginning of a labor biography and the creation of their own family. The most important students' personal attainment of this age is the ability to draw up life plans, seek means for their implementation, and develop social and moral ideals that testify to self-awareness. In the current study, as a novel strategy, it was tried to present the recent problem of engaging, stimulating, and developing the social and cultural communication and activity of university students. The article also contains conceptual ideas and principles of the model construction for the student's social activity formation; generalized results of the students' survey on the motives for their participation in this type of activity are presented. The article deals with modern interpretations of the concepts of students in the social and cultural activity process in the university.

\section{Methods}

The word "participation" literally means "gathering and gathering" for a specific purpose. There has been a lot of discussion about its idiomatic meaning, but in general, its main essence can be considered as conflict, activity, and influence. From a lexical point of view, the concept of partnership is different from cooperation, collaboration, and otherness. In some texts, however, these words are used interchangeably. The concept of participation has been interpreted several times. The variety of interpretations has led some to liken it to a bag of luck that some tend to take out of it whatever they want.

GUTMAN, Eugeniya, TERENTYEVA, Irina, GAIDAMASHKO, Igor and FAKHRUTDINOVA, Anastsiya. Students involvement into social and cultural activity: modeling and motivation. ECORFAN Journal-Mexico. 2021 
Experts and experts' perceptions of the concept of partnership are different but close to each other. Most definitions of partnership emphasize the issue of participation in decisionmaking as an essential element, but there is no consensus on other aspects. In sum, the definitions, nature, and content of unity participation are not taken into account. As many authors believe, it is impossible to provide a universal definition of participation. A review of the definitions of participation can help us to define the community. Due to the fact that there is no single theory that can explain the discussion of social participation and the factors affecting it, in the present study, a combined theoretical framework using independent research variables has been used to explain the relationship between these variables and social participation.

Learning is a social process, and learning activities are critical to reaching the stage of producing ideas and information. Teachers in schools are faced with three educational situations; in most cases, they choose one of them. In each class, teachers may organize lessons in such a way that students are forced to strive to win. They also allow students to learn as they wish, and in some cases, teachers organize students to learn in groups with the help of each other. But in most cases, it is seen that the student works alone in the classrooms. Each student is told to do your own thing. The advantage of student participatory methods is that students actively participate in teaching-learning activities and take responsibility for learning. During discussions with people in their group and with other groups, they learn how to express their thoughts, insights, and opinions to others, how to defend them, or how to politely accept the opinions of others. This method is very effective in strengthening students' communication skills.

\section{Results and Discussions}

Today, the development of higher education depends on the following factors: the formation of a knowledge-based society; Advances in information communication; The process of globalization and integration from there, we can see significant changes in the role, goals and conditions of higher education, which operates as a social institution. The educational procedure should consider the psychological patterns related to the age of human development.
At the same time, it should be noted that the issues of the formation of the student's socioprofessional activity using cultural activity in the conditions of a higher professional school have not been studied enough. Meanwhile, it is social and cultural activity as a purposeful process of creating conditions for the motivated choice of the substantive work by the individual. This substantive work is determined by the presented opportunities and interests, contributes to the formation of social activity that provides effectiveness in professional training (Shakirova, 2018; Hurtado et al., 2021; Quevedo Sánchez, 2021). It also helps to unite the student's collective, allows forming personal qualities such as initiative, consciousness, responsibility, etc.

The adopting of content, ideals, meanings, and value orientations occurs through various forms and methods of subject-forming social and cultural activities that ensure personal self-realization. The process of formation of social activity in this regard can be represented as the interaction of two trends: socialization and individualization. Suppose the first consists in the appropriation by an individual of his social essence. In that case, the second is in developing an individual way of life, thanks to which a person gets the opportunity to develop oneself according to own natural inclinations and social needs.

\section{Structural model of the university student's social activity formation}

In the course of our research, the structural model of the university student's social activity formation in the process of cultural activity is built on the basis of integrity, completeness, coherence, interdependence, and mutual subordination of its components: goals, objectives, pedagogical conditions, principles, stages, levels and criteria for the social activity formation (Alavi et al., 2005). One of the purposes of forming social activities is for students to become active leaders and organizers of activities. It is necessary to provide a number of conditions: provide a variety of activities at the university that provide an opportunity to choose the type of promotion. Maintain a certain level of teacher training and engagement based on the unity of goals and values. Student self-government and social activities are a special form of initiative, independent, responsible activities aimed at the solution of important questions of activity of students' youth, development of its social activity, support of social initiatives, and the formation of common cultural competencies (Terentyeva, 2017). 
At the heart of the developed model lie the following conceptual ideas:

Cultural activity should cover a wide range of forms that contribute to the social activity formation.

For each student's year, cultural activity should be planned in such a way that it contributes to the motives for social activity formation.

Every kind of cultural activity should solve the task of developing motives and real possibilities of a socially active person.

Every kind of cultural activity should create prerequisites for the transfer of motives and real opportunities to other types of students' social and professional activities.

With the help of surveys, observations, and conversations, the qualitative characteristics of student social activity were revealed: the display of initiative, diligence, consciousness, responsibility in various types of social and cultural activities.

The process of forming student participation is carried out in a variety of important social and useful activities. We are very important for stimulating student participation: clubs, creative associations, studios, actors and business events, role-playing in various fields. The most basic structural model of promoting the student from the goal of educational activities to the subject of social activity is of educational importance that assumes the independent activity and experience of students in extracurricular time (Shakirova, 2018). This trend in higher education is achieved through extracurricular activities, student associations (volunteer centers, scientific associations), holding social events that encourage students to participate in important social activities. Participation in social projects (festivals, volunteer work) under the guidance of the Youth Committee; All projects implemented in the University Press Center are covered. In practice, students had the opportunity to participate in all administrative processes: assessing the situation and identifying problems. Resource evaluation; Set goals and tasks. Planning; Personnel affairs; Decision making; Monitoring and Evaluation Work Organization; Conclusion; Analysis (Holden, 2002).
The Students Survey "Your motives for participating in social activity.”

The motives of students' participation in social and cultural activities according to the results of our research conducted in 2017-2019 have the following dates: to be socially useful - 19\%, contribute to changes in society - $10 \%$, selfrealization $-26 \%$, a sense of duty - $19 \%$, interesting spending of leisure time - $15 \%$, solve their own problems - $11 \%$.

We can divide these motives into 3 groups:

- $\quad$ The desire to solve own problems of various natures; to determine own capabilities, interests, strengths and weaknesses.

- $\quad$ Satisfying the need to be needed.

- $\quad$ Pragmatic motives - career growth, prospects, and interesting leisure.

Research has shown that leisure and sports have become the most attractive destination for students, among other types of volunteering. This may be justified by a large number of world-class competitions and entertainment held in Kazan.

\section{Conclusions}

As mentioned earlier, the current study presents the recent problem of engaging, stimulating, and developing university students' social and cultural communication and activity. The article also contains conceptual ideas and principles of the model construction for the student's social activity formation; generalized results of the students' survey on the motives for their participation in this type of activity are presented.

Thus, based on the conducted research, it can be concluded that the personality social activity is a dynamic property, which reflects social and professional orientation and expresses the readiness to be included in various types of life activities, including those related to the future profession. Further study of the problem of improving social activity can be continued in the direction of the formation of student social and professional activity in integrating educational social and cultural activities in a university in the context of the formation of a Common Education Space. 


\section{Acknowledgements}

The work is performed according to the Russian Government Program of Competitive Growth of Kazan Federal University.

\section{References}

Alavi, M., Kayworth, T. R., \& Leidner, D. E. (2005). An empirical examination of the influence of organizational culture on knowledge management practices. Journal of management information systems, 22(3), 191-224.

Arnold, N., \& Ducate, L. (2006). Future foreign language teachers' social and cognitive collaboration in an online environment. Language Learning and Technology, 10(1), 42.

Fakhrutdinova, A. V., Ramsiya, N. G., Eveleva, A., \& Shamsutdinova, D. V. (2019). Paradigmatic methodology of civic culture formation process in young generation. Journal of Sociology and Social Anthropology, 10(4), 198-202.

Fletcher Jr, E. C., Warren, N. Q., \& HernándezGantes, V. M. (2018). Preparing high school students for a changing world: College, career, and future ready learners. Career and Technical Education Research, 43(1), 77-97.

García Padilla, B. R. (2021). Fortalecimiento del pensamiento crítico de los estudiantes de décimo grado, mediante experiencias estéticas visuales.

Gutman, E. V. (2013). Socio-pedagogical support of university students as a factor in their personal and professional formation. Kazan Pedagogical Journal, 1, 108-114.

Holden, N. (2002). Cross-cultural management: A knowledge management perspective. Pearson Education.

Hurtado, J. L., Boronat, M. E., Rosés, A., Rodríguez, J. C., Valera, O., \& Aguilera, A. R. (2021). 1.3 Marco conceptual para la elaboración de una teoría pedagógica. Compendio de pedagogía, 45.

José Sá, M. (2020). 'The secret to success'. Becoming a successful student in a fast-changing higher education environment. European Journal of Higher Education, 10(4), 420-435.
Levina, E. Y., Akhmetov, L. G., Latipova, L. N., Mirzagitova, A. L., Mirzanagimova, F. I., Latipov, Z. A., \& Masalimova, A. R. (2015). Diagnostics of Educational Activity Quality on the Basis of Qualitative Methods. Asian Social Science, 11(4), 246-251.

Loginova, YU. N. (2006). The concept of an individual educational route and an individual educational trajectory and the problem of their construction. Library journal Methodist, 9, 4-7..

Mashanov, A. A., Rostovtseva, M. V., Khokhrina, Z. V., \& Yurdanova, V. N. (2014). Methodological research vectors of personality social adaptation. Life Science Journal, 11(12), 825-829.

Maslennikova, V.Sh., Bogovarova V.A., \& Shaikhutdinova G.A. (2010). Portfolio of a curator as a technology for assessing his educational activities: a methodological manual. Kazan. 2010.

Onufriieva, L. (2016). Theoretical and methodological aspects of the genesis of future socionomic specialists' professional personality. Fundamental and applied researches in practice of leading scientific schools, 15(3), 132-140.

Popovych, I. S. (2016). Applied research aspect of social expectations of personality in English scientific literature. Проблеми сучасної психології, (31), 355-366.

Quevedo Sánchez, E. M. (2021). Estrategias de gestión institucional basado en la motivación para fomentar la satisfacción laboral docente en la Institución Educativa $\mathrm{N}^{\circ} 182$ ciudad de Pacanga, distrito y provincia de Chepén, región La Libertad, 2017.

Romanova, E. S., Abushkin, B. M., Ovcharenko, L. Y., Shilova, T. A., \& Akhtyan, A. G. (2018). Socialization Factors of Schoolchildren: Psychological Aspect. Astra Salvensis.

Sakhieva, R. G., Khairullina, E. R., Khisamiyeva, L. G., Valeyeva, N. S., Masalimova, A. R., \& Zakirova, V. G. (2015). The Syllabus of the Regional Component of Professionally Motivational Education Developed for the Students Specializing in Tourism. Asian Social Science, 11(2), 246-251.

Shakirova, A., \& Gizyatova, L. (2018). Forms of students' academic mobility organization in Russian universities. ORBIS, 14, 65-73. 
Sibgatova, K. I., Mirzagalyamovva, Z. N., Pupysheva, E. L., Mirzanagimova, F. I., Shkinderova, I. N., Nuriyeva, E. N., ... \& Schepkina, N. K. (2015). The educational institution teachers and professional community representatives' readiness formation for the joint pupils' career guidance implementation. Rev. Eur. Stud., 7, 74.

Slastenin, V. A. (2004). Professionalism of a Teacher as Phenomenon of Pedagogical Culture. Pedagogical education and science, (4), 4-15.

Terentyeva, I.V., Pugacheva, N.B., Lunev, A.N., Selivanova, O.G. (2017). Managment of the formation of general common cultural competencies of the university students. Modern Journal of Language Teaching Methods, 7(6), 1120.

Tough, A.M. (2007). Social Activity of Students: concepts and practice in C.J. Titmus (ed.) Lifelong Education for Adults. An international handbook. Oxford..

Yudkevich, M. (2014). The Russian University: recovery and rehabilitation. Studies in Higher Education, 39(8), 1463-1474.

Yusof, N., Awang-Hashim, R., Kaur, A., Malek, M. A., Shanmugam, S., Manaf, N. A. A., ... \& Zubairi, A. M. (2020). The Role of Relatedness in Student Learning Experiences. Asian Journal of University Education, 16(2), 235-243. 